\title{
Empowering Local Tourism Providers to Innovate through a Living Lab Process: Does Scale Matter?
}

\section{David Guimont and Dominic Lapointe}

\author{
"Why don't we scale up those things that do work? ") \\ Tavis Smiley \\ Broadcaster, author, and entrepreneur
}

\begin{abstract}
A destination management organization looking to integrate technology into its tourism offering tasked a living lab with engaging tourists and tourism providers in the process. At the end of the two-year initial funding period for an action research project, the process is a success and stakeholders are engaged in the innovation ecosystem. But what is next? By observing participants and gathering feedback from stakeholders through a Policy Delphi panel, the outcomes of the project and the intentions and actions of the tourism providers and other parties were identified. Innovation capacity has increased: spin-offs were created and stakeholders have embraced open and collaborative innovation. Now, stakeholders are determined to make the process sustainable by finding other funding sources. But what should be the level of cooperation and intervention? What level can best foster innovation and knowledge retention? A case study combining a grid of characteristics and levels of analysis for living labs was used to identify one key question: for a living lab in tourism, does scale matter? This article will explore that question and will contribute to the understanding of the living lab as a model of socio-territorial action.
\end{abstract}

\section{Introduction}

To grow and develop, businesses must innovate (Schumpeter, 1934). The tourism industry is no different: it needs to innovate so that businesses and destinations can evolve and stand out. Because of its fragmented and multi-stakeholder nature, the tourism industry is particularly well suited to open and collaborative innovation (Egger et al., 2016). Some believe that the competitiveness of destinations is determined by their capacity to reinvent themselves by offering new products and services that recombine the partnerships between the various elements of the territory's tourism offering (Pikkemaat \& Weiermair, 2011). Although destinations struggle to innovate (Najda-Janoszka \& Kopera, 2014), opening up the innovation process by engaging stakeholders in a living lab project could stimulate innovation (Lapointe \& Guimont, 2015).

Open innovation is about increasing and improving collaboration with an ecosystem's stakeholders and en- gaging users in the co-creation process. The living lab approach aims to promote and structure stakeholder collaboration, and its key feature is that users become fully fledged stakeholders in the co-creation process and are involved from the very beginning, in a real-life environment. Through living labs, "tourist service providers will obtain insight into what tourists actually want and will have an opportunity to improve and develop new services targeted to different customer segments"

(Pucihar et al., 2014). Such insight (from the living lab) could not only enable identification of new markets, but also spur innovation, development, and product improvement (Buhalis \& Amaranggana, 2014) through more frequent interactions among stakeholders in a partnership. With interactions between users (tourists) and providers of technology and tourist services being a key catalyst for innovation (Hjalager, 2002), living lab could create increased collaboration opportunities through a common platform where stakeholders would share, discuss, assess, and design various solutions 


\section{Empowering Local Tourism Providers to Innovate through a Living Lab Process}

\section{David Guimont and Dominic Lapointe}

(Pucihar et al., 2014). In addition, living labs have the potential to become innovation facilitators (Lapointe \& Guimont, 2015; Schuurman et al., 2013) and thus create what destination management organizations are struggling to build: an environment that promotes co-operation among tourism industry stakeholders to enable innovation (Najda-Janoszka, 2013).

The living lab under consideration in this article deals with a geography-based activity: tourism. A living lab is not only an innovation process (Bergvall-Kåreborn \& Ståhlbröst, 2009); it is also a physical space, a place where innovation happens, a territorial development tool (Lafontaine \& Gallant, 2013), and a form of socioterritorial action (Doyon et al., 2015).

Living labs often use a territory as a focus for development or innovation. However, few researchers have examined the matter of selecting a scale for intervention, although some authors have defined scales of concertation and intervention (Bergvall-Kåreborn et al., 2015; Doyon et al., 2015; Franz et al., 2015,). When living labs deal with strongly territorial industries, such as tourism (Lapointe et al., 2015) and agriculture, the need to reflect on scales and levels of action emerges.

To advance reflection on these matters, we used the three-levels grid of analysis proposed by Schuurman and colleagues (2015) to describe the case of a tourism industry living lab (Lapointe et al., 2015). We are attempting to highlight how the framework applies to the reality of the pilot project in order to identify gaps, particularities, and similarities that could provide insight into the scaling and sustainability of the implemented innovation ecosystem.

The article is structured as follows. First, we will review the literature on living labs and levels of innovation. Then, we will apply the three-level framework to an action research project in living lab mode with the tourism industry. Finally, we will discuss the relevance of combining levels of innovation process with socio-territorial geographic scales.

\section{Literature Review}

With the living lab approach, users must be at the centre of research or innovation efforts. Instead of attempting to understand users through studies, some organizations now prefer to directly involve users in their actual innovation process (Westerlund \& Leminen, 2011). This co-creation approach stimulates innovation and delivers a number of benefits: better grasp of consumers' latent needs, lower risk of failure in product and service design, shorter lead times for new products and services, and higher profits (Westerlund \& Leminen, 2011).

Living labs usually include the following features and principles (Bergvall-Kåreborn et al., 2009):

- a technology infrastructure

- an ecosystem of stakeholders who can interact to develop and assess products, services, processes, or systems

- an innovation process that is as open as possible (e.g., regarding intellectual property and types of partnership)

- users playing a key role as co-creators of the products, services, and technologies being developed

- a human-centric design approach that involves ethnographic observation, empathy, and rapid prototyping

- sustained and meaningful interaction and community involvement

\section{- consideration of users' natural environments}

Living labs also provide "physical regions or virtual realities in which stakeholders form public-private-people partnerships (PPPP) of firms, public agencies, universities, institutes, and users all collaborating for creation, prototyping, validating, and testing of new technologies, services, products, and systems in real-life contexts" (Westerlund \& Leminen, 2011).

According to Schuurman and colleagues (2015), the living lab approach combines practices from both the open innovation and user innovation paradigms: "Open Innovation can be used to study the knowledge transfers on the constellation level, whereas User Innovation can provide insights into user contribution and user involvement methods." This observation stems from the three-level model proposed by the same authors: open innovation happens at the macro level (the living lab constellation) and user innovation happens at the micro level (user contribution and engagement methods), while the living lab project (innovation project) is between the two, at the meso level. 


\section{Empowering Local Tourism Providers to Innovate through a Living Lab Process}

\section{David Guimont and Dominic Lapointe}

With their three-level model (Table 1), they propose the following definition (Schuurman et al., 2015):

\author{
"Living Labs are an approach to innovation \\ consisting of three separate, but interrelated levels \\ of analysis. On the macro level, Living Labs are a \\ Public-Private-People partnership organized to \\ exchange knowledge and conduct innovation \\ projects. We regard these Living Lab innovation \\ projects, that are characterized by active user \\ involvement, co-creation, multi-method and \\ multi-stakeholder, as the meso level. These projects \\ consist of different research steps that are aimed at \\ generating user input and contribution to the \\ innovation process, which we consider to be the \\ micro level."
}

This article will apply this three-level model to analyze a living lab project in the tourism sector, which is not technology intensive. We will combine this model with the territorial scales (macro, meso, and micro) to describe and understand how innovation level and territorial scales can be combined in a socio-territorial model of action.

We will use this grid to characterize the ongoing living lab project and to explore possible options for sustainable engagement. However, these levels refer to the processes implemented to stimulate innovation, not to geographic scales. Nevertheless, when the innovation process is integrated into an economic sector that is deeply rooted in a given territory, reflections on the correspondence between innovation levels and geographic scales can be fruitful.

\section{Living labs and territoriality}

In a paper demonstrating the transferability of the living lab approach as a model of socio-territorial action, Franz and colleagues (2015) argue that "living labs have the potential to be an instrument for the active inclusion of citizens in urban research projects investigating socio-spatial questions." They use the term "space of encounter" to describe the space where citizens converge naturally, and where the living lab is moved to take this natural tendency into account. They discuss spaces of encounter (meso level) as well as the time and nature of encounters (micro level).

According to Leminen, DeFillippi, and Westerlund (2015), who identified paradoxical tensions in the living lab approach, larger scales are better because they maximize stakeholder diversity and knowledge retention, and because larger user pools are easier to segment.
Table 1. Levels of analysis for living labs (Schuurman, 2015; Schuurman et al., 2015)

\begin{tabular}{ll}
\hline Levels & Description \\
\hline Macro & $\begin{array}{l}\text { Living lab constellation (ecosystem, public- } \\
\text { private-people partnership) }\end{array}$ \\
\hline Meso & Living lab innovation project \\
\hline Micro & Living lab methodological research steps \\
\hline
\end{tabular}

However, local needs and contexts should be taken into account. These authors believe that combining several local contexts into a broader ecosystem is beneficial.

To integrate living lab characteristics into a territorial conception of innovation, we can say that a living lab is both an approach and a milieu/environment (BergvallKåreborn et al., 2009), where the milieu is a continuum between the macro level (constellation) and the micro level (methodological research steps). This continuum of physical, social, and virtual spaces enables governance, concertation, and knowledge retention (at the macro level) as well as interventions, user involvement, co-creation, experimentation, and evaluation (at the meso and micro levels). In cases with a territorial dimension, such as the tourism industry, living labs would feature relatively broad concertation and cooperation territories roughly following official administrative space. It also encompasses, at a lower geographic scale, spaces of encounter and intervention (e.g., space of encounter, virtual community, real-life context) where people are in close physical or virtual proximity. These spaces following social and lived spaces at meso and micro geographic scales.

\section{Methodology}

We conducted action research to document the iterative co-creation process behind the design of a technology-enhanced tourist experience, which was conceptualized according to the needs and actions of tourists discovering a new destination. The living lab is used as "an approach to support and implement processes of open innovation in the context of academy-society collaboration projects" (Levén \& Holmström, 2008). The role of lead researchers is to oversee the living lab process, prepare co-creation workshops, and facilitate co-creation both in situ and online. They lead the "experimentation" component. They describe how innovation capability is growing, and the drivers and 


\section{Empowering Local Tourism Providers to Innovate through a Living Lab Process}

\section{David Guimont and Dominic Lapointe}

barriers at play. The collaborating researchers support the co-creation process, deliver specific workshops on technology and the tourist experience, and help to document and characterize the growth in innovation capability. It is done using case study methodology (Yin, 2011).

In this case study, we captured user feedback iteratively and sometimes led to modifications of the processes. There were multiple opportunities for feedback and evaluation by users: before, during, and after activities; during workshops; and during field testing. Our action research in a living lab context relied on an adaptation of the FormIT approach (Bergvall-Kåreborn et al., 2009). The role of the lead researcher was to oversee the process, prepare co-creation workshops, and facilitate co-creation both in situ and online.

Two sources of data were used to describe the case and analyze the innovation processes. The first source was all the documents and notes produced by the partners involved in the process, which includes text data from a tourist panel and from an in situ observation of tourists using the innovations. The second source of data was a Policy Delphi (Linstone \& Turoff, 2002) exercise run through 10 stakeholders involved in the process.

\section{Case Study - When Technology Meets Territory: Co-Creation of a Technology- Enhanced Tourist Experience}

Through this article, we continue our analysis of an innovation project in a living lab setting that included a higher-education institution, a destination management organization, a technology developer, tourism providers, and tourists. The destination management organization for Rivière-du-Loup in Quebec, Canada, wanted to improve tourists' sightseeing experience using technology. Its intention was to produce podcasts. The local higher-education and research institution, the Cégep de Rivière-du-Loup (cegeprdl.ca), offered support for living lab projects, and the destination management organization tasked the institution with bringing together all stakeholders listed above and launching an action research project. The intention of the project was then transformed by the stakeholders into getting creative distance by introducing the users' inputs into the project of co-creating a technology-enhanced tourist experience in a living lab setting (Guimont \& Lapointe, 2015) for the discovery of the rural areas of the county.
The two-year project involved a community of tourism providers and tourists and used a combination of virtual and in situ collaborative processes to conceptualize, prototype, and test the tourist experience. The project provided an opportunity to achieve co-creation in a living lab setting. A mobile application (ICI Rivière-duLoup) was conceptualized and prototyped during the first year of the project, and was tested and refined during the second year.

In terms of living lab characteristics, the project is a small, but typical living lab. The following subsections describe the levels of analysis.

\section{Macro level: Living lab constellation}

The macro level is where stakeholders in the innovation ecosystem come together and discuss the planning and governance of the area or industry where user-driven innovation is needed. The macro level is the group of stakeholders that choose the specific living lab projects to be conducted. It is where knowledge and expertise accumulate. In the ongoing project under consideration, the macro and meso levels overlap to form a single level, as is often the case in less mature living lab structures that work on a single project. Indeed, in this action research project, the governance, and the planning are done by the same key stakeholders who are leading the co-creation process at the meso level. These stakeholders include a technology provider, a destination management organization, and the local higher-education and research institution, which is also a living lab called LLio: Living lab en innovation ouverte (Living Lab in Open Innovation; llio.quebec).

For the moment, the research question of the living lab constellation (macro) is the research question of the living lab project (meso): How can we create a technologyenhanced tourist experience - and how can we integrate this approach at the destination level?

The macro level, based on the model by Schuurman and colleagues (2015), could improve transfer and retention of the knowledge accumulated through living lab projects (meso level). In the case under consideration, training could be offered to stakeholders outside the living lab project. Tools and documents could be circulated, and documents could be shared in a monitoring and curation context. In the three-level model, the macro level (the living lab constellation) is viewed as a structure that can accommodate various projects. Accordingly, the "co-creating a technology-enhanced 


\section{Empowering Local Tourism Providers to Innovate through a Living Lab Process}

\section{David Guimont and Dominic Lapointe}

tourist experience" project would be the first project, and others could follow, either in the same community or in a different territory or subindustry within the living lab constellation.

Even though the macro and meso levels overlap in the current living lab structure by having the same key stakeholders, some impacts at the macro level can be identified:

- increased strategic thinking/tourist intelligence (appropriation of the Destination 2.0 concept, which refers to the technological participation of the tourist destination in creating, marketing, and commenting on the destination and the tourist experience principles)

- greater capacity for innovation among tourism providers (Lapointe et al., 2015)

- knowledge retention (collaborative methods, tourist experience and co-creation concepts, and technology concepts and prototypes)

- transfer of knowledge and know-how to members of the destination management organization through technology demonstrations, document circulation, and training on technology, tourism, co-creation of tourist experiences and Destination 2.0

- identification of opportunities (e.g., technology-enhanced tourist experience concepts that the destination's stakeholders can experiment with)

- identification of research funding opportunities where the living lab engagement space becomes a forum for a national-scope project (e.g., climate change)

In the two rounds of the Policy Delphi exercise, all 10 participants rated the integration of all elements of the Destination 2.0 model (Neuhofer et al., 2014) into the destination strategy as very important or important. They identified the living lab as an enabler, but they also pinpointed the importance of extending their new capacities to the whole destination.

\section{Meso level: Living lab innovation project}

The meso level guides the innovation project conducted using a living lab approach. In the case under consideration, the meso level is the steering committee made up of representatives from three stakeholders (the teaching and research institution/living lab, the technology provider, and the destination management organization). The committee plans the key project stages and approves inputs and outputs at each stage. The lead researcher plans individual workshops in more detail. So far, the living lab project (meso level) has enabled the development of two mobile apps, has improved innovation capacity, and has provided a physical and virtual space for engagement and co-creation.

\section{Micro level: Living lab methodologies}

The micro level focuses on the timing and content of cocreation meetings and user interactions. At this level, through various in situ and online workshops and through observation, tourists' needs and expectations are identified and concepts are co-created, co-developed, and eventually tested by users in the field. These various types of interactions take place in spaces of encounter and interaction. In the living lab project under consideration, the following spaces were used:

- a collaborative space at the local college (used by the LLio living lab) for co-creation workshops and training sessions

- a tourist information centre and museum institution for field observations

- a secret Facebook group, SurveyMonkey, Google Drive, and a website for data collection and interactions

\section{Discussion}

In the project under consideration, the meso and macro levels overlap. In a more mature living lab structure, the meso level would likely be associated with a specific innovation project like the ongoing one, while the macro level - within a broader territory or industry - could supervise multiple innovation projects and optimize knowledge retention and transfer. The meso level would provide a reusable but adaptable template that could be applied to various individual cases and subterritories across the living lab constellation.

The starting point for the innovation project is local (a county), and so is the project's scale, with the local destination management organization, the regional highereducation institution, and a local technology provider. This is a meso scale of intervention. All tourism providers were also local. The tourist community was made up of people (users) from within and outside the region. Assuming that the research question and the living lab structure were applied at the macro level in order for 


\section{Empowering Local Tourism Providers to Innovate through a Living Lab Process}

\section{David Guimont and Dominic Lapointe}

the living lab to mature and to consolidate its operations, what would be the appropriate scale? Local, regional, supra-regional, national, or industry-wide?

Although Schuurman and colleagues (2015) argue that knowledge and expertise retention happens at the macro level, and while Leminen and colleagues (2015) suggest that a very broad user pool increases opportunities for innovation, applying the macro level to a strongly territorial industry such as tourism raises the following question: What is the appropriate scale of intervention? Perhaps the overlapping in our case is due not only to the living lab's low maturity level, but also to the context, given that tourism practices are deeply rooted in a physical and social space. Nevertheless, the macro level could become more relevant by breaking away from the meso level and focusing on the micro level.

Accordingly, if the living lab structure were to be applied at a broader macro level, conditions for success would need to be reproduced at the micro level: spaces of encounter for co-creation and training, real-life user observation and engagement contexts, and a technology infostructure (information technology structure) to engage users remotely. Most expertise developed through the living lab project was at the micro level. However, the omnipresence of living lab coordination at all three levels of the current project raises the thorny question of transfer between levels. Such transfer needs to involve a wide range of stakeholders at the micro and meso levels while maintaining a measure of consist- ency at the macro level. In the current project, transfer happened organically, with stakeholders at the micro level appropriating techniques and processes in order to apply them to other projects they are involved in at the meso level. However, the ecosystem's low maturity level and the territorial specificities of the tourism industry prevent us from determining whether the macro level encompasses all projects that benefit from the spread of living lab processes.

We therefore believe that the question of territories and scales is extremely relevant when considering living lab interventions in a regional development context, especially in strongly territorial industries such as tourism. Although there is overlap in our case, such overlap does not hinder reflection. However, it is necessary to combine innovation process levels, geographic scales, and living lab characteristics to arrive at a descriptive grid that can guide reflection on both innovation and scales for a sustainable living lab process, eventually leading to the institutionalization of the living lab process at the appropriate territorial scale.

An institutionalization territory (Lévesque \& Vaillancourt, 1998) is a territory where a body of social relationships can be maintained over time; it remains sustainable while continuing to evolve. The diversity of interventions and types of living labs calls for formal institutionalization levels that can promote sustainability of the relationships created by living labs. Table 2 summarizes the links between innovation process levels, territory levels, and living lab characteristics.

Table 2. Links between levels and characteristics of living labs

\begin{tabular}{|c|c|c|c|}
\hline & Innovation Process Levels & Territory Levels & Living Lab Characteristics \\
\hline Macro & Living lab constellation & Concertation / governance & $\begin{array}{l}\text { - Ecosystems approach } \\
\text { - Real-world context } \\
\text { - Technical infrastructure } \\
\text { - Lifespan } \\
\text { - Scale } \\
\text { - Level of openness }\end{array}$ \\
\hline Meso & Living lab project & Intervention / steering & $\begin{array}{l}\text { - Technical infrastructure } \\
\text { - Community } \\
\text { - Level of openness }\end{array}$ \\
\hline Micro & Living lab methodologies & Socialization / encounter & $\begin{array}{l}\text { - Real-world context } \\
\text { - User role } \\
\text { - Level of openness } \\
\text { - Evaluation, context research, and co-creation }\end{array}$ \\
\hline
\end{tabular}




\section{Empowering Local Tourism Providers to Innovate through a Living Lab Process}

\section{David Guimont and Dominic Lapointe}

\section{Conclusion}

By applying the three-level living lab analysis model to our tourism living lab project, we observed that the current project's micro level matches the micro level described in the literature. However, the current project merges the macro and meso levels into a single level, with no hierarchical or territorial distinctions. Returning to Schuurman and colleagues (2015), we can state that the two levels of innovation, macro and meso, are led by the same stakeholders in different processes but sometimes at the same time, with the territorial scale being the same: the scale of the local county. We also found that a broader scale at the macro level might be preferable, although the low maturity of the living lab under consideration makes it hard for us to determine whether the ideal scale would be regional, supra-regional, or national. These results raised questions about the appropriate territorial scale for ensuring sustainability and efficiency in a living lab. The overlapping of the macro and meso level raised issues of diversity in terms of the different points of view "at the table" but also in terms of the diversity of territorial governance at play in the project.

Living labs are not working in a neutral deterritorialized context; they work on a territorial context at a scale or another. Our analysis of the action research shows that, as a territorial model of action, the living lab acts at different territorial scales. We therefore proposed a descriptive grid that merges the levels of the innovation process with the scales of the territory associated with the living lab's areas of intervention. Future research will be required to test this grid and to probe deeper into the relationships between innovation, living labs, territories, and territorial industries involved in living labs.

\section{Acknowledgments}

This research is funded by the Ministère de l'Éducation et de l'Enseignement supérieur du Québec (Programme d'aide à la recherche et au transfert - Volet innovation sociale).

An earlier version of this article was presented at the 2016 International Conference on Tourism (ICOT) Innovation Conference, which was held in Naples, Italy from June 29 to July 6,2016 , in collaboration with the International Association for Tourism Policy (IATOUR; iatour.net), a non-profit organization dedicated to promoting scientific tourism research.

\section{About the Authors}

David Guimont is a Teacher-Researcher at the Cégep de Rivière-du-Loup in Quebec, Canada, where he is associated with the Recreation and Leadership Training Department and the Living Lab in Open Innovation (LLio). He holds a master's degree in Tourism Management and Development from the Université du Québec à Montréal (UQAM).

Dominic Lapointe is a Professor in the Department of Urban Studies and Tourism at the Universite du Québec à Montréal (UQAM) in Canada, where he is the Director of the Tourism and Hospitality Management Undergraduate program. His research addresses development and environmental issues with the use of critical theory, especially in the fields of tourism, conservation, and the environment. He holds a doctoral degree in Regional Development from the Université du Québec à Rimouski (UQAR).

\section{References}

Bergvall-Kåreborn, B., \& Ståhlbröst, A. 2009. Living Lab: An Open and Citizen-Centric Approach for Innovation. International Journal of Innovation and Regional Development, 1(4): 356-370. http://dx.doi.org/10.1504/IJIRD.2009.022727

Buhalis, D., \& Amaranggana, A. 2014. Smart Tourism Destinations. In Z. Xiang \& L. Tussyadiah (Eds.), Proceedings of the International Conference on Information and Communication Technologies in Tourism: 553-564. Switzerland: Springer International Publishing. http://dx.doi.org/10.1007/978-3-319-03973-2_40

Doyon, M., Rochman, J., Fontan, J. M., Klein, J. L., Ducruc, S., Xiao, J., Yorn, C., Fortin, J., \& Dugré, S. 2015. L'approche Living Lab et l'aménagement des espaces ouverts agricoles. Un exemple en région métropolitaine de Montréal. Articulo - Journal of Urban Research, Special Issue 6. http://dx.doi.org/10.4000/articulo.2662

Egger, R., Gula, I., \& Walcher, D. 2016. Towards a Holistic Framework of Open Tourism. In R. Egger, I. Gula, \& D. Walcher (Eds.), Open Tourism: Open Innovation, Crowdsourcing and Co-Creation Challenging the Tourism Industry: 3-16. Berlin: Springer. http://dx.doi.org/10.1007/978-3-642-54089-9_1

Franz, Y., Tausz, K., Thiel, S., \& Yunus, M. 2015. Contextuality and CoCreation Matter: A Qualitative Case Study Comparison of Living Lab Concepts in Urban Research. Technology Innovation Management Review, 5(12): 48-55. http://timreview.ca/article/952

Guimont, D., \& Lapointe, D. 2015. Co-Creation of a Tourist Experience Enhanced by Technology in the Context of a Living Lab. e-Review of Tourism Research. ENTER 2015 (6). 


\section{Empowering Local Tourism Providers to Innovate through a Living Lab Process David Guimont and Dominic Lapointe}

Hjalager, A.-M. 2002. Repairing Innovation Defectiveness in Tourism. Tourism Management, 23(5): 465-474.

http://dx.doi.org/10.1016/S0261-5177(02)00013-4

Lafontaine, D., \& Gallant, N. 2013. Des laboratoires vivants pour des territoires innovants. Centre facilitant la recherche et l'innovation dans les organisations (CEFRIO).

http://www.cefrio.qc.ca/media/uploader/Laboratoires_vivants_ra pport_synthese.pdf

Lapointe, D., \& Guimont, D. 2015. Open Innovation Practices Adopted by Private Stakeholders: Perspectives for Living Labs. info, 17(4): 67-80.

http://dx.doi.org/10.1108/info-01-2015-0003

Lapointe, D., Guimont, D., \& Sévigny, A. 2015. The Living Lab Approach to Raise Innovation Capability Among Tourism Practitioners. Tourism Dimension, 2(2): 18-27.

Leminen, S., DeFillippi, R., \& Westerlund, M. 2015. Paradoxical Tensions in Living Labs. In Proceedings from the XXVI ISPIM Conference, June 14-17, 2015, Budapest, Hungary.

Levén, P., \& Holmström, J. 2008. Consumer Co-Creation and the Ecology of Innovation: A Living Lab Approach. Proceedings of IRIS31, August, 10-13.

http://www.diva-

portal.org/smash/record.jsf?pid=diva2\%3A311009\&dswid=-102

Lévesque, B., \& Vaillancourt, Y. 1998. Les services de proximité au Québec: de l'expérimentation à l'institutionnalisation. Montréal: Université du Québec à Montréal.

Linstone, H. A., \& Turoff, M. (Eds.). 2002. The Delphi Method: Techniques and Applications. Upper Saddle River, NJ: AddisonWesley.

Marez, L. D., Schuurman, D., \& Ballon, P. 2015. Bridging the Gap between Open and User Innovation? Exploring the Value of Living Labs as a Means to Structure User Contribution and Manage Distributed Innovation. Ghent: Ghent University. https://biblio.ugent.be/record/5931264

Najda-Janoszka, M., \& Kopera, S. 2013. Exploring Barriers to Innovation in Tourism Industry - The Case of Southern of Poland. Procedia - Social and Behavioral Sciences, 110: 190-201. http://dx.doi.org/10.1016/j.sbspro.2013.12.862

Najda-Janoszka, M. 2013. Innovative Activity of Small Tourist Enterprises - Cooperation with Local Institutional Partners. Journal of Entrepreneurship, Management and Innovation, 9(1): $17-32$.

http://mpra.ub.uni-muenchen.de/id/eprint/52991

Neuhofer, B., Buhalis, D., \& Ladkin, A. 2014. A Typology of Technology-Enhanced Tourism Experiences. International Journal of Tourism Research, 16(4): 340-350. http://dx.doi.org/10.1002/jtr.1958
Pikkemaat, B., \& Weiermair, K. 2007. Innovation through Cooperation in Destinations: First Results of an Empirical Study in Austria. Anatolia, 18(1), 67-83. http://dx.doi.org/10.1080/13032917.2007.9687036

Pucihar, A., Malešič, A., Lenart, G., \& Borštnar, M. K. 2014. UserCentered Design of a Web-Based Platform for the Sustainable Development of Tourism Services in a Living Lab Context. In L. Caporarello, B. Di Martino, \& M. Martinez (Eds.), Lecture Notes in Information Systems and Organisation, 7: 251-266. Switzerland: Springer International Publishing. http://dx.doi.org/10.1007/978-3-319-07040-7_24

Santoro, R., \& Conte, M. 2009. Living Labs in Open Innovation Functional Regions. In Proceedings from the 15th International Conference on Concurrent Enterprising, June 22-24, 2009. http://dx.doi.org/10.1109/ITMC.2009.7461431

Schaffers, H., Guzmán, J. G., \& Merz, C. 2008. An Action Research Approach to Rural Living Labs Innovation. In P. Cunningham and M. Cunningham (Eds), Proceedings of the Collaboration and the Knowledge Economy: Issues, Applications, Case Studies: 617-624. Amsterdam: IOS Press.

Schuurman, D. 2015. Bridging the Gap between Open and User Innovation? Exploring the Value of Living Labs as a Means to Structure User Contribution and Manage Distributed Innovation. Doctoral dissertation. Ghent University and Vrije Universiteit Brussel VUB.

Schuurman, D., De Marez, L., \& Ballon, P. 2013. Open Innovation Processes in Living Lab Innovation Systems: Insights from the LeYLab. Technology Innovation Management Review, 3(11): 28-36. http://timreview.ca/article/743

Schuurman, D., De Marez, L., \& Ballon, P. 2015. Living Labs: A Structured Approach for Implementing Open and User Innovation. Paper presented at the 13th Annual Open and User Innovation Conference, July 13-15, 2015, Lisbon, Portugal. http://hdl.handle.net/1854/LU-6888241

Schumpeter, J. 1934. The Theory of Economic Development. Boston: Harvard University Press.

Westerlund, M., \& Leminen, S. 2011. Managing the Challenges of Becoming an Open Innovation Company: Experiences from Living Labs. Technology Innovation Management Review, 1(1): 19-25. http://timreview.ca/article/489

Yin, R. K. 2011. Applications of Case Study Research. London: SAGE Publications.

Citation: Guimont, D., \& Lapointe, D. 2016. Empowering Local Tourism Providers to Innovate through a Living Lab Process: Does Scale Matter? Technology Innovation Management Review, 6(11): 18-25. http://timreview.ca/article/1031

Keywords: living labs, tourism, destination management, innovation, scale, level, territoriality, socio-territorial action, action research 